\title{
Strategies to target long non-coding RNAs in cancer treatment: progress and challenges
}

\author{
Behdokht Fathi Dizaji
}

\begin{abstract}
Background: Long non-coding RNAs are important regulators of gene expression and diverse biological processes. Their aberrant expression contributes to a verity of diseases including cancer development and progression, providing them with great potential to be diagnostic and prognostic biomarkers and therapeutic targets. Therefore, they can have a key role in personalized cancer medicine.

This review aims at introducing possible strategies to target long ncRNAs therapeutically in cancer. Also, chemical modification of nucleic acid-based therapeutics to improve their pharmacological properties is explained. Then, approaches for the systematic delivery of reagents into the tumor cells or organs are briefly discussed, followed by describing obstacles to the expansion of the therapeutics.

Main text: Long ncRNAs function as oncogenes or tumor suppressors, whose activity can modulate all hallmarks of cancer. They are expressed in a very restricted spatial and temporal pattern and can be easily detected in the cells or biological fluids of patients. These properties make them excellent targets for the development of anticancer drugs. Targeting methods aim to attenuate oncogenic IncRNAs or interfere with IncRNA functions to prevent carcinogenesis. Numerous strategies including suppression of oncogenic long ncRNAs, alternation of their epigenetic effects, interfering with their function, restoration of downregulated or lost long ncRNAs, and recruitment of long ncRNAs regulatory elements and expression patterns are recommended for targeting long ncRNAs therapeutically in cancer. These approaches have shown inhibitory effects on malignancy. In this regard, proliferation, migration, and invasion of tumor cells have been inhibited and apoptosis has been induced in different cancer cells in vitro and in vivo. Downregulation of oncogenic long ncRNAs and upregulation of some growth factors (e.g., neurotrophic factor) have been achieved.

Conclusions: Targeting long non-coding RNAs therapeutically in cancer and efficient and safe delivery of the reagents have been rarely addressed. Only one clinical trial involving IncRNAs has been reported. Among different technologies, RNAi is the most commonly used and effective tool to target IncRNAs. However, other technologies need to be examined and further research is essential to put IncRNAs into clinical practice.
\end{abstract}

Keywords: Long non-coding RNA, Therapeutic target, Systematic delivery, Cancer treatment 


\section{Background}

Long non-coding RNAs (lncRNAs) are a major group of non-coding RNAs. Similar to mRNA, they are transcribed by RNA polymerase II, $5^{\prime}$ capped, and polyadenylated at $3^{\prime}$ end. However, they do not have proteincoding capacity. They have exon/intron and dynamic secondary or tertiary structures $[1,2]$. LncRNAs act widely in numerous aspects of gene regulation, including $\mathrm{X}$ chromosome inactivation, genomic imprinting, epigenetic regulation, transcription, mRNA splicing, and nuclear and cytoplasmic trafficking [2, 3]. They are crucial regulators of biological processes such as cell cycle, proliferation, differentiation, metabolism, apoptosis, and maintenance of pluripotency $[4,5]$. LncRNAs function in different ways. Scaffold lncRNAs have domains that recruit various effectors [6]. Guide lncRNAs guide the ribonucleoprotein complexes to specific locations [7]. Decoying lncRNAs bind to their targets and inhibit their functions [8]. Signaling lncRNAs act as molecular signals in cellular processes such as activation of gene transcription by enhancer RNAs (eRNAs) or X chromosome inactivation $[9,10]$.

Comparative transcriptomic and genome-wide association studies (GWAS) indicated that single nucleotide polymorphisms (SNPs) in lncRNAs are associated with cancer and several other diseases [11, 12]. Engagement of lncRNAs in all of ten cancer hallmarks has been documented [13-16]. LncRNAs show low expression in normal conditions. However, they are upregulated or downregulated during cancers [17]. Deregulated lncRNAs are involved in the cancer-associated alterations at transcriptional and translational levels [18]. For example, some lncRNAs are associated with transcription factors (TF). Studies on glioblastoma revealed that dysregulation of these lncRNAs leads to tumorigenesis. They form specific lncRNA-TF-gene triplets such as HOX transcript antisense RNA-max-interacting protein1 CD58 antigen, lymphocyte function-associated antigen 3 , and protein kinase C epsilon (HOTAIR-MXI1-CD58/PRKCE) and HOX transcript antisense RNA-activating transcription factor 5 and neural cell adhesion molecule1 (HOTAIRATF5-NCAM1). This enhances their target gene expression and, in turn, contribute glioblastoma prognosis [19]. The metastasis-associated lung adenocarcinoma transcript 1 (MALAT1) is known to regulate alternate splicing and modulate the activity of spliceosome complex, which is essential for correct splicing and activity of a transcription factor, Myb-related protein B $(B-M y b)$, that involves in second growth phase G2 phase/mitosis $M$ phase (G2/M) transition. Thus, elevated expression of MALAT1 in cancer tissues leads to hyper-proliferation [20].

LncRNAs function as oncogenes and tumor suppressors in cancers. Oncogenic lncRNAs such as nuclear enriched abundant transcript1 (NEAT1), antisense non- coding RNA in the INK4 locus (ANRIL), HOTAIR, and MALAT1 fulfill the definitions of oncogenes. HOTAIR is a transcript from the antisense strand of the homeobox gene $(H O X C)$ cluster. It is overexpressed in solid tumors and promotes tumor progression, invasion, metastasis, and poor prognosis [21]. HOTAIR recruits histone methylase polycomb repressive complex 2 (PRC2) and lysinespecific histone demethylase 1A (LSD1) to the target gene promoters. Tri-methylation at the 27th lysine residue of the histone H3 protein (H3K27me3) and demethylation at lysine 4 (H3K4) occurs which can result in gene silencing of some tumor suppressor genes [22]. LncRNA HOTAIR is deregulated in hepatocellular and colorectal carcinomas, pancreatic tumors, ovarian cancer, and sarcomas [23-27]. In esophageal cancer, HOTAIR enhances cell invasion and metastasis and promotes the epithelial-mesenchymal transition (EMT), since it functions as a miR-148a sponge and positively regulates a transcription factor, zinc finger protein SNAI2 (Snail2) expression [28]. MALAT1 localizes the nucleus and participates in RNA splicing and gene expression at transcriptional and posttranscriptional levels [29]. It involves proliferation, migration, invasion, metastasis, or apoptosis of tumor cells. The upregulation of MALAT1 is associated with various types of cancers including breast, lung, bladder cancers, esophageal squamous cell carcinoma, and glioma [30-33].

LncRNAs also act as tumor suppressors: the maternally expressed gene 3 (MEG3), growth arrest specific 5 (GAS5), neuroblastoma-associated transcript-1 (NBAT-1), and long intergenic non-protein coding RNA, P53induced transcript (LINC-PINT) have key roles in cellular processes. They are downregulated in cancers. LINC-PINT localizes downstream of p53 and acts as its regulatory effector and inhibits tumor invasion [34]. Its downregulation contributes to tumorigenesis in mouse models and LINC-PINT expression is lost in many tumors [35]. MEG3 is a polyadenylated lncRNA. Its imprinted gene is on the delta-like non-canonical notch ligand1-the maternally expressed gene 3 (DLK1-MEG3) locus of chromosome $14 \mathrm{q} 32.2$ [36]. MEG3 has high expression in normal human tissue, which is stimulated by cyclic adenosine monophosphate (cAMP). Highly expressed MEG3 inhibits proliferation and promotes apoptosis of tumors through interactions with different microRNAs [37-39]. Besides, $M E G 3$ shows decreased or no expression in many cancers namely, brain, lung, colon, liver, and leukemia. MEG3 expression is under epigenetic control, and aberrant $\mathrm{CpG}$ methylation has been demonstrated in several types of cancer [37, 40]. MEG3 involves the modulation of transforming growth factor-b (TGF-b) pathway genes that affect cell invasion and immune regulation. In addition, it activates p53 [41, 42]. Some lncRNAs can act both as oncogenes and tumor suppressors such as V-Raf murine 
sarcoma viral oncogene homolog B1 (BRAF)-activated noncoding RNA (BANCR), lncRNA of H19 gene (H19), $\mathrm{X}$-inactive specific transcript (XIST), and MALAT1 [43].

LncRNAs have the potential to be diagnostic or prognostic biomarkers and therapeutic targets, since they are expressed in a cell, tissue, developmental, or diseasespecific manner. Several lncRNAs are only expressed in cancer cells [44-47]. The prostate cancer antigen 3 (PCA3) promotes the proliferation and invasion of prostate cancer. PCA3 has been approved as a urine biomarker for prostate cancer. This IncRNA exhibits better specificity and sensitivity compared to the prostate-specific antigen (PSA) test $[48,49]$. It is over-expressed 60- to 100 -fold in prostate tumors compared to benign prostatic tissue and is undetectable in other cancer types $[50,51]$.

The existing approaches for the treatment of cancer are suboptimal. Targeting lncRNAs can replace or supplement present strategies because they are minimally invasive and convenient therapeutic targets. This review illustrates the potential of IncRNAs as prospective therapeutic targets in cancer. Strategies of targeting cancerassociated lncRNAs therapeutically to modulate their level or function are discussed. Also, chemical modification of nucleic acid-based therapeutics to improve their pharmacological properties is explained. Finally, approaches for the systematic delivery of reagents into the tumor cells and challenges in targeting lncRNAs are described.

\section{Main text}

\section{Targeting IncRNAs in cancer treatment}

LncRNAs could be promising therapeutic targets in cancer. They are easily detectable in the saliva, serum, plasma, urine, and tissues of cancerous patients. Their flexible and complex structures can be targeted while they are participating in cellular complexes. Specific expression of lncRNAs provides the possibility of killing cancer cells selectively. Their low expression allows the use of lncRNA targeting drugs at lower doses, thereby avoiding toxicities relevant to oligonucleotide therapies. Unlike cellular signaling pathways that encompass signal amplification cascade, IncRNAs function at absolute expression levels that facilitate easier manipulation. In addition, strategies such as enzyme replacement therapy that have been designed to restore deficient or eliminated expression of genes have side effects. Targeting lncRNAs might be an alternative to upregulate such genes in a locus-specific pattern [52, 53]. In this regard, various strategies have been developed to suppress oncogenic lncRNAs or alter their epigenetic effects. Besides, technologies to interfere with their functions have been designed. LncRNAs regulatory elements and expression patterns have been recruited for cancer treatment. Moreover, downregulated or lost lncRNAs can be restored as natural drugs.

\section{Suppression of oncogenic IncRNAs}

Oncogenic lncRNAs are upregulated in cancers so they can be targeted via using different technologies to reduce their levels. Here, these techniques are described, which, among them, nucleic acid-based methods have dominated. Furthermore, these technologies allow the functional analysis of lncRNAs and targeting epigenetic modifications.

\section{Antisense oligonucleotides (ASOs)}

Antisense oligonucleotides (ASOs) are single-stranded antisense oligonucleotides with a DNA stretch (at least $6 \mathrm{mer}$ ) at the central part, which is native, or phosphorothioated (chemically modified) and RNA nucleotides at flanking parts of the molecule. DNA forms RNA/DNA heteroduplex with target lncRNA that will be cleaved by endogenous RNaseH1 [54]. ASOs typically are used to alter mRNA expression and have succeeded in treating several diseases $[55,56]$. They can be exploited to suppress highly expressed lncRNAs in cancers. Several designs of ASOs including locked nucleic acid GapmeRs (LNAGapmeRs), antagonist to NATs (antagoNAT), and mixmers are used with different modes of action.

\section{Locked nucleic acid GapmeRs (LNA GapmeRs)}

LNA GapmeRs are very similar to ASOs in structure and function (16 nucleotides), except that they have chemically modified LNA in flanking arms whereas the gap DNA segment lacks the LNA. LNA increases binding affinity and nuclease resistance. Phosphorothioated backbones have been designed to make GapmeRs resistant to enzymatic degradation [57].

Researchers designed two LNAs for targeting different regions of repeat $\mathrm{C}$ on lncRNA XIST through base pair formation. They were used to study the localization of XIST along the X chromosome. Repeat C consists of 14 tandem repeats with a c-rich sequence, situated $3 \mathrm{~kb}$ downstream of repeat $A$ that is a silencing domain at the 5 ' end [58]. A localization domain was detected, and displacement of polycomb repressive complex 2 (PRC2) and XIST coincided. This study suggested that PRC2 and XIST bind to different sites of the $\mathrm{X}$ chromosome at the same time and do not occupy all binding sites immediately, while the displacement of XIST from X takes place with fast kinetics. However, H3K27me3 marks and gene silencing were stable. As a result, the LNA technology allows high-throughput functional analysis of lncRNAs and may provide an opportunity to target epigenetic modifications in vivo for therapeutic applications [59].

\section{Antagonist to NATs (antagoNATs)}

Natural antisense transcripts (NATs) are coded from the opposite strand to the host gene locus. They are divided into cis-NATs that regulate the expression of the sense 
transcripts of the same locus and into trans-NATs, which regulate the expression of a transcript from other genomic loci [12]. NATs mediate transcriptional silencing of the related loci via histone-modifying complexes. The antagonist to NATs is a single-stranded oligonucleotide that is designed to inhibit sense-antisense interactions. Therefore, it can be used for the elimination of the epigenetic silencing effect of NATs. Brain-derived neurotrophic factor $(B D N F)$ transcription naturally is repressed by BDNF-AS. In a study to target, activate brain-derived neurotrophic factor antisense (BDNF-AS) in vivo, DNA-based, antagoNAT gapmer with three LNA substitutions at each end and phosphorothioatemodified backbones was built to activate $B D N F$ expression. This resulted in $B D N F$ mRNA upregulation, which led to increased protein levels and induced neuronal outgrowth and differentiation in vitro and in vivo [60]. Thus, antagoNAT strategy provides a useful tool for targeting lncRNAs that act as natural antisense NATs to genes of therapeutic interest.

\section{Mixmers}

Mixmers comprise chemically modified nucleotides such as LNA and different types of monomers. They do not have ordinary sequential DNA nucleotides and are not a substrate for RNase H1. Therefore, they sterically inhibit the linkage between IncRNA, ribonucleoproteins, or nucleic acids. They can be used to prevent epigenetic remodeling complexes, alter gene expression, which is regulated by pseudogene transcript, redirect alternative splicing, repair defective RNA, and restore protein production [61, 62]. Researchers designed OMe/LNA (2'-O-methyl/LNA) mixmers that suppressed transactivation response element-transactivator of transactivation (TAT-TAR) interactions by the steric blockade in Hella cells. The replication of human immunodeficiency virus type 1 (HIV-1) depends on these interactions. Also, a tricyclo-DNA/oligonucleotides (16 nucleotides) mixmer inhibited expression of $\beta$-galactosidase in Hella cells [62].

\section{Small interfering RNAs (siRNAs) and short hairpin RNA (shRNAs)}

Small interfering RNA (siRNA) is a knockdown strategy. siRNAs are short double-stranded RNAs. They unwind into single strands, attach to RNA-induced silencing complex (RISC), and create a base pair with a lncRNA of interest, leading to argonaute degradation of the target transcript [63] (Fig. 1). RNAi has different forms, including transcriptional and posttranscriptional gene silencing. RNAi libraries consist of synthetic or enzymatic interfering RNAs. Treatment of double-strand RNA (dsRNAs) with Dicer or RNase III provides endoribonuclease-made siRNAs (esi-RNAs), which are directly delivered into the cytoplasm. Chemically synthesized siRNAs represent the conventional forms, which also are delivered into the cytoplasm directly. Although both siRNAs cause strong suppression of target transcripts, their effect is temporary. Conventional siRNAs indicate a more off-target effect compared to esi-RNAs. Another form of RNAi is short hairpin RNA (shRNA), which is expressed inside the cell. shRNAs yield silencing responses that may be transient or stable and show a much more off-target effect than esi-RNAs. Tumor cells are transfected by shRNA or siRNA plasmid vectors [64].

A siRNA mediated knockdown of second chromosome locus associated with prostate-1 (SChLAP1), resulting in reduced cell proliferation and invasiveness. LncRNA SChLAP1 causes aggressive prostate cancer by preventing the tumor-suppressive activity of the SWItch/Sucrose Non-Fermentable (SWI/SNF) complex [65].

MALAT1 expression levels are highly increased in cervical cancer (CC) cells and tissues. A plasmid vector with a DNA fragment, encoding hairpin RNA, was used to attenuate MALAT1 levels. Also, an shRNA vector lacking hairpin oligonucleotides as a negative control was built. This strategy prevented metastasis and invasion in vitro and in vivo in CC cells. Downregulation of MALAT1 increased E-cadherin and Zonula occludens-1 (ZO-1) while decreased b-catenin, vimentin, and transcription factor snail. Hence, MALAT1 is a target for the inhibition and therapy of cervical cancers [66].

Researchers demonstrated that novel pyk-reg-90-containing $\ln c R N A(N-B L R)$ is highly expressed in gastric cancer cell lines and tissues compared to normal gastric cells and adjacent normal tissues. Two siRNAs significantly reduced cell proliferation and suppressed migration and invasion of gastric cancer cells. LncRNA $N-B L R$ expression was inversely associated with miR-200c, which is known to regulate EMT. Therefore, NBLR proves to be a regulator of the EMT process in gastric cancer [67].

Short hairpin RNAs to knockdown three molecules, secretory carrier membrane protein 1 lncRNA (SCAMP1), transcription factor LIM homeobox transcription factor 1 alpha $(L M X 1 A)$, and NLR family, CARD domain containing5 (NLRC5) gene, were constructed in a vector. The oncogenic function of (SCAMP1) was repressed in glioma cells. Inhibition of $S C A M P 1$ prevented cell proliferation, migration, and invasion while induced apoptosis due to acting as a molecular sponge of miR-499a-5p. This microRNA acts as a tumor suppressor in glioma cells because it targets the $3^{\prime}$ untranslated ( $3^{\prime}$-UTR) region of $L M X 1 A$, which is upregulated in glioma cells and tissues. $L M X 1 A$ activates the NLRC5 expression that stimulates the $\mathrm{Wnt} / \beta$-catenin signaling pathway, which promotes the malignancy of glioma cells. Therefore, targeting the SCAMP1/miR-499a-5p/ $L M X 1 A / N L R C 5$ pathway can be a new therapeutic approach for glioma treatment [68]. 
Scientists built siRNAs to knockdown, SOX2 overlapping transcript (SOX2OT), MALAT1, and ANRIL. Furthermore, a universal siRNA as a negative control without homology with mammalian gene sequence was designed. Down-regulation of polycomb group RING finger protein 1 (NSPC1) expression with MALAT1, SOX2OT, and ANRIL prevented the proliferation and raised apoptosis in primary glioblastoma cell line (U87) cells. This result indicated that MALAT1, SOX2OT, and ANRIL combine and crosstalk with NSPc1 in U87 glioblastoma cells to modify proliferation and apoptosis [69].

siRNAs can also be used for NAT-related dysregulation, to target the antisense transcript in a region that does not directly overlap the sense transcript $[60,70]$.

\section{Deoxyribozymes and ribozymes}

Deoxyribozymes are enzymatic DNA molecules with one strand, synthesized to bind to the target RNA according to Watson-Crick base pairing rule. They catalyze RNA cleavage, resulting in fragments of $2^{\prime}, 3$ '-cyclic phosphate and 5 '-hydroxyl ends. They also mediate bond formation via ligation between the 3 '-hydroxyl and 5 '-triphosphate terminal in RNA [71, 72] with the help of $\mathrm{Ca} 2, \mathrm{Mg} 2$, $\mathrm{Pb} 2$, andZn2 cofactors [73].

Scientists have designed site-specific cleaving deoxyribozymes, which are sensitive to the modified nucleotide $N^{6}$ methyladenosine (m6A) in cellular RNAs (Fig. 2). They were used to investigate the methylation state of DG (m6A/A) CH motifs (D = A, G, or U; $\mathrm{H}=\mathrm{A}, \mathrm{C}$, or $\mathrm{U}$ ). One type of these DNA enzymes offered faster cleavage of methylated RNA, whereas others were significantly prevented by the modified nucleotide. In humans, IncRNA MALAT1 A 2577 contains m6A [74, 75]. Treatment of this lncRNA with one of these DNA enzymes (VMC10) confirmed the high methylation of the target site [76].

Engineered ribozymes with better catalytic activities and substrate recognition domains have been designed to gain new diagnostic and therapeutic applications. They cleave RNA independent of protein at specific sites in cis or trans [77].

The hammerhead ribozyme (HHRz) has been found in all species. The secondary structure of the HHRz contains three variable stems (stem I/II/III). They are linked to a central catalytic core of 13 conserved nucleotides that is vital for self-cleaving. The cleavage occurs behind the nucleotides (GUC $\downarrow$ ) (Fig. 3, hammerhead ribozyme). The catalytic activity of the HHRz is boosted by threedimensional interaction between the loop in stem II and the bulge in loop I [78]. Engineered HHRz was created using two independent molecules. Splitting of loop III resulted in a transformation from intramolecular ciscleavage to intermolecular trans-cleavage. NUX $\downarrow$ group is essential for the cleaving site. Here, $\mathrm{N}$ is any nucleotide, $\mathrm{U}$ is uridine, and $\mathrm{X}$ stands for any nucleotide except guanosine [79] (Fig. 3, engineered ribozyme). Any RNA molecule containing inner NUX $\downarrow$ that matches the HHRz binding arms can be cleaved in trans [80, 81]. Some researchers claimed this ribozyme could not cleave efficiently at GUG $\downarrow$ site. They designed hammerhead ribozymes with a new cleaving site, "DWH" $(\mathrm{D}=\mathrm{A} / \mathrm{U} /$ $\mathrm{G}, \mathrm{W}=\mathrm{A} / \mathrm{U}$, and $\mathrm{H}=\mathrm{A} / \mathrm{U} / \mathrm{C})$ and an optimal binding arm length of (8-9 nucleotides) to achieve trans-cleavage of a single-stranded RNA molecule [82].

\section{Genome engineering tools}

Zinc finger nucleases (ZFNs), transcription activator-like effector nucleases (TALENs), and clustered regularly interspaced short palindromic repeats (CRISPR)/Cas9 system are genome-engineering approaches, which can be recruited to decrease lncRNA expression levels. The genome can be manipulated by ZFNs in a site-specific manner. RNA destabilizing elements (RDE) were integrated into the locus of MALAT1 by utilizing ZFNs in human cancer cells. Its expression was decreased 1000

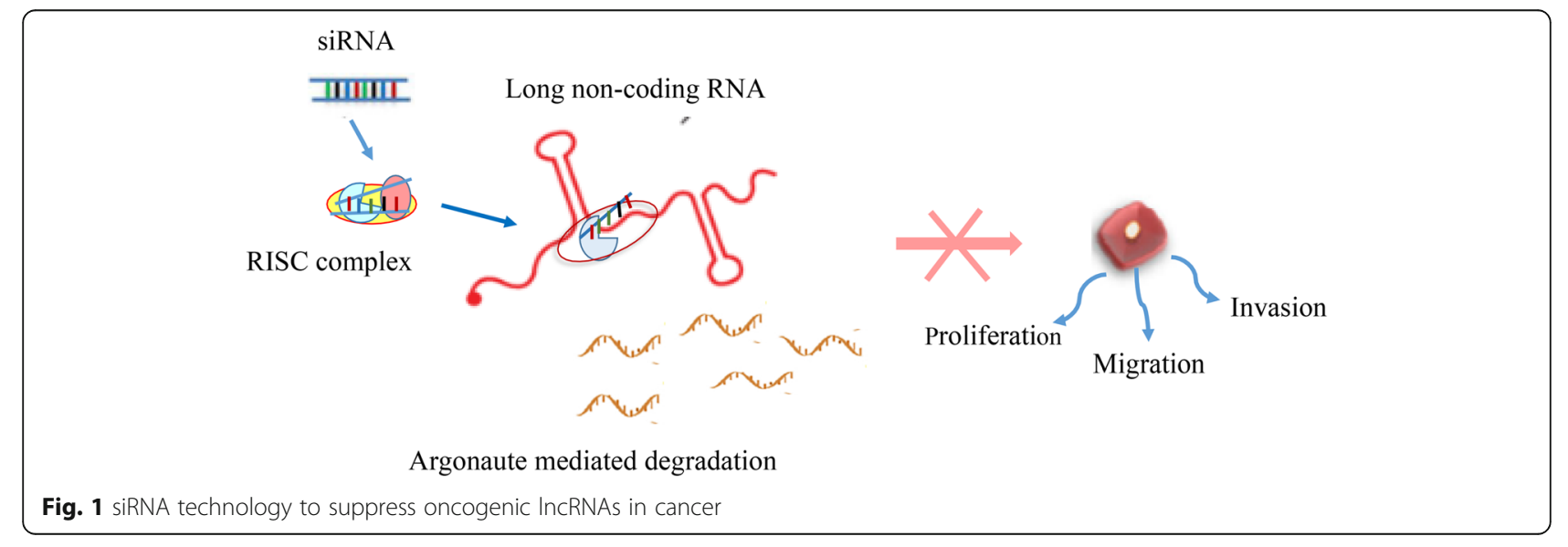




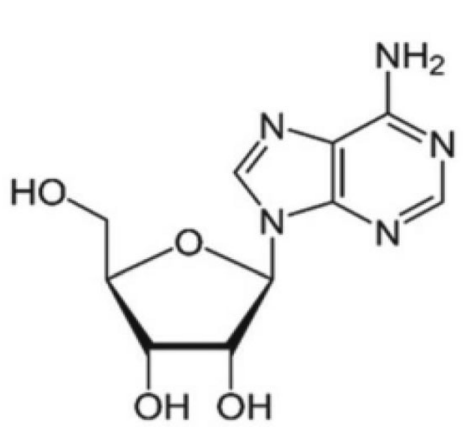

Adenosine<smiles>CNc1ncnc2c1ncn2C1OC(CO)C(O)C1O</smiles>

$\mathrm{N}^{6}$ - methyladenosine

Fig. 2 Adenosine (left); $\mathrm{N}^{6}$-methyladenosine (right)

\section{Hammerhead ribozyme}

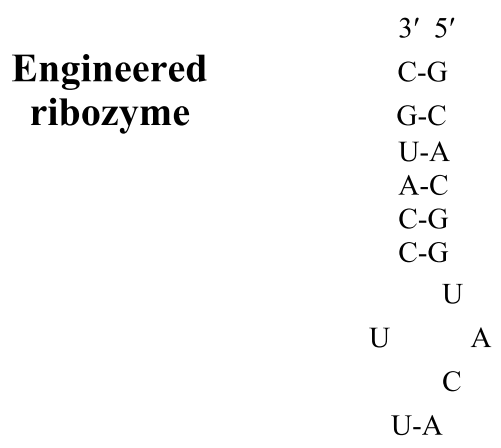

Cleave site

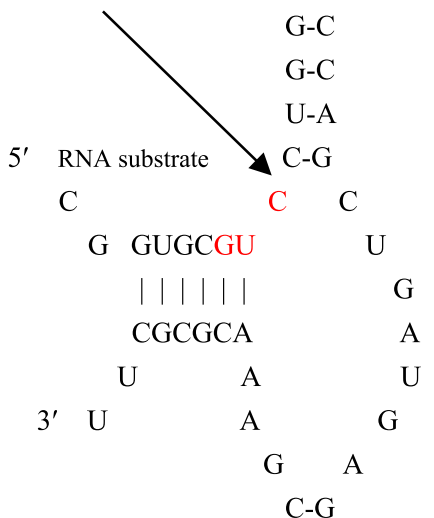

A-U

$\mathrm{G}-\mathrm{C}$

G-C

A C

U A

A A

Trans cleaving

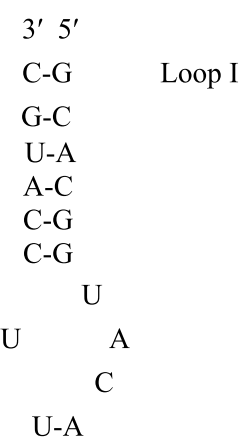

A-U

Cleave site

C-G

C-G

U-A Central core of

13 conserved nts

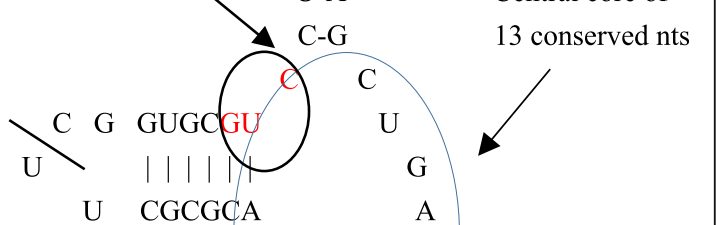

A

A

G A

C-G

A-U

G-C

$\mathrm{G}-\mathrm{C}$

$$
\text { A C }
$$

U A Loop II

A A

Cis cleaving 


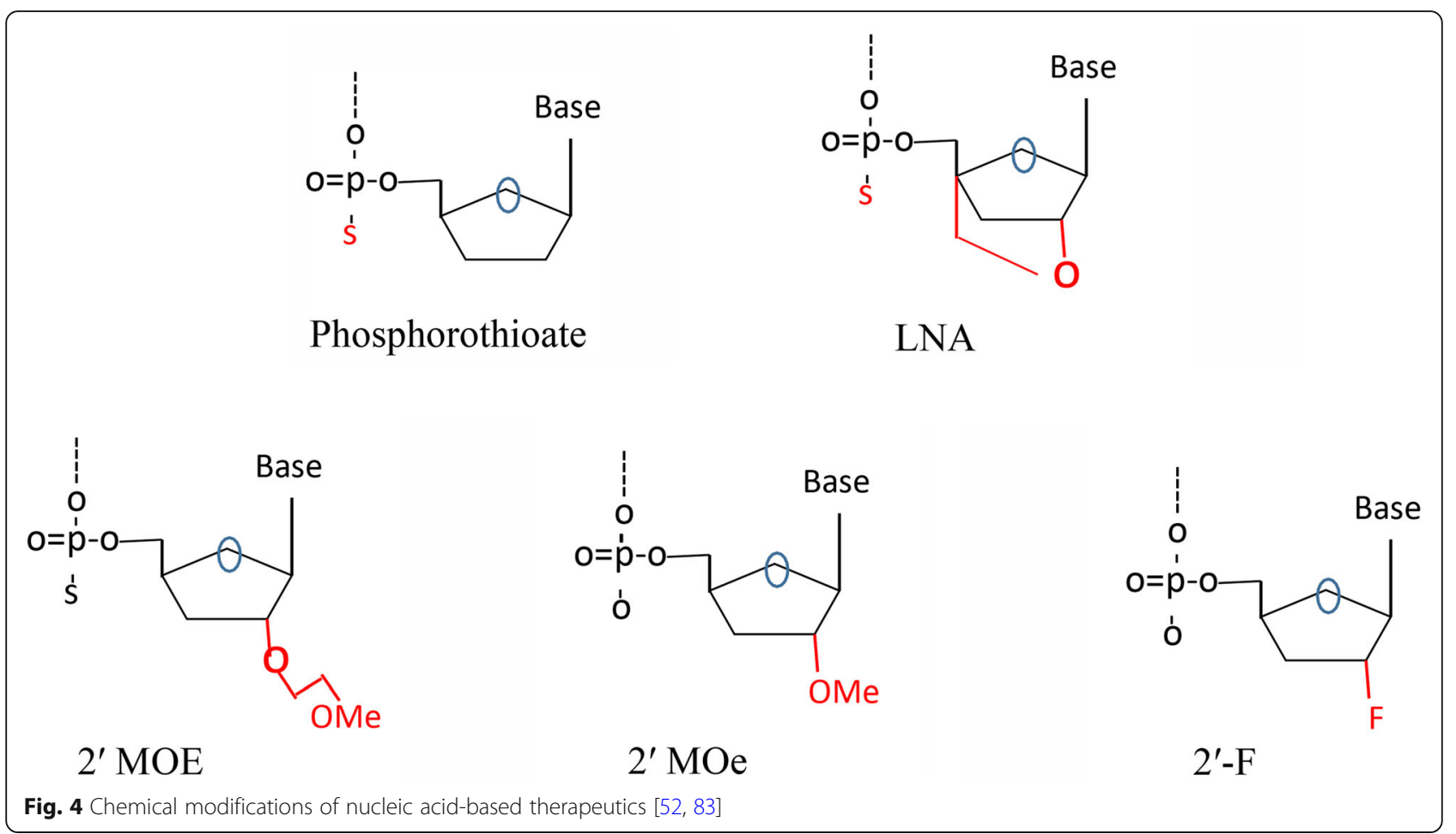

fold in stable knockout colons, inferring a loss of function model $[84,85]$. Although this inactivation did not affect alternative splicing, fewer tumor nodules and cell migration were observed in mouse xenograft revealing that MALAT1 has the potential to be a therapeutic target to prevent metastasis in lung cancer [30]. RDEs are integrated into the genome loci such as poly-A signals leading to the silencing of downstream sequences by acting as termination elements. Also, pseudogenes can be silenced by RDE [84, 86].

Unlike protein-coding genes, long ncRNA genes are not vulnerable to a few base insertion, deletion, or frameshift mutations. Thus, they may act through general structures that should be manipulated on large scales. This is possible utilizing the CRISPR/Cas9 system and paired single guide RNAs (sgRNAs) whereby $23 \mathrm{~kb}$ of Rian, a maternally expressed lncRNA gene, was deleted in mice. Also, the deletion efficacy was enhanced by using numerous sgRNAs, and deletions were inherited as well [87].

Transcription of lncRNA genes can be suppressed sterically by CRISPR interference (CRISPRi). CRISPRi comprises a guide RNA (gRNA) to recognize the target gene and catalytically dead Cas9 (dCas9) protein without endonucleolytic activity [88]. gRNAs target template strand sequences, or regions that are $100 \mathrm{bp}$ upstream of the promoter, or non-template DNA strand in the promoter, or -35 regions. This is more effective in eukaryotic cells compared to direct blockage of RNA polymerase [88]. Also, dCas 9 can be integrated into a repressor domain,
Kruppel-associated box (KRAB), that leads to the silencing of gene expression epigenetically [89].

\section{Strategies to interfere with LncRNAs function}

To target lncRNAs function several technologies namely, small molecules, nanobodies, aptamers, and RNA decoys have been proposed to disrupt interactions between lncRNA/protein via competition or steric blockade [53].

\section{Small molecules}

Small molecules bind to either lncRNA or RNA-binding proteins (RBP), change their secondary or tertiary structures, or directly mask protein-binding sequences of RNAs or lncRNA binding domain of the RBPs to disrupt interactions between them [90]. Thus, a profound understanding of LncRNA-protein interactions is essential to meet this goal. Various methods have been developed for the identification of the physical interactions between lncRNAs and proteins. For example, using methods like capture hybridization analysis of RNA targets (CHART) and RNA affinity purification (RAP), proteins that bind to functional intergenic repeating RNA element (FIRRE), XIST, MALAT1, and NEAT1 with relevant gene sequences were identified. These methods are categorized as the RNA-centric study of RNA-protein interactions in vivo via cross-linking [91-93].

Quantitative analysis of these interactions at a large scale is vital to investigate small molecule modulators [94]. Technologies such as high-throughput sequencingRNA affinity profiling (HiTS-RAP) assay and RNA on a 
massively parallel array (RNA-MaP) can be adopted for this purpose [95]. Meanwhile, databases and libraries of small molecules that modulate ncRNAs can be explored $[96,97]$. X-ray crystallography and nuclear magnetic resonance (NMR) spectroscopy may help to create structural models to find out how small molecules are attached to and fit in the lncRNA-protein binding cleft [94].

PerkinElmer (Waltham, MA) technology was introduced to quantify the IncRNA-protein interaction, named AlphaScreen technology. Based on AlphaScreen technology, the interaction of HOTAIR and BDNF-AS, with enhancer of zeste homolog 2 (EZH2), was assessed. Besides, ellipticine was discovered, which upregulates the BDNF transcription [90].

Targeting lncRNA-protein interactions lead to reversible inhibition of chromatin-modifying enzymes in their noncatalytic domains since it is illustrated that these enzymes have different sites for long ncRNA binding [94].

In a breast cancer model, small molecules have been used to interfere with the interactions of HOTAIR and PRC2 or LSD1 complexes to limit the metastatic potential of tumors [98].

LncRNA MALAT1 does not have a polyA tail; however, it has a very unusual 3 '-terminal structural motif, known as the stability element for nuclear expression (ENE) [99]. A triple helix is formed through interactions between a U-rich hairpin and the transcript 3' A-rich tail. This ENE motif protects MALAT1 from degradation and high levels of transcript accumulate in the nucleus $[100,101]$. Using a small molecule microarray strategy, two ligands were detected, which specifically bind to the mouse Malat1 ENE triplex. They had 90\% homology with human MALAT1 ENE triplex [101]. Both ligands decreased Malat1 RNA levels in cell culture and branching morphogenesis in a mammary tumor model by inducing structural changes, (but in different ways). One of the ligands regulated Malat1 downstream genes whereas it did not affect lncRNA Neat1 that possesses a similar ENE triplex structure. This illustrates the specificity of this ligand for Malat1 over another virus-coded ENEs and Neat1 [102].

\section{Nanobodies}

Nanobodies are capable of disrupting cancer-related RNA-protein networks. They are a variable part of camelid heavy-chain antibodies (HcAbs) with high affinity and specificity. Besides, they are very stable and soluble antigen-binding proteins, with similarity to human Immunoglobulin heavy chain $\mathrm{V}$ gene $(\mathrm{VH})$ sequences; thus, they are non-immunogenic. They interfere with proteinnucleic acid or protein-protein interactions and have the capacity to interrupt cancer-specific RNA-RBP networks [103].
Researchers designed a gene library of synthetic nanobodies, able to bind to nucleic acids. A nanobody (cAbBC1rib3) was identified that specially binds to $\phi B C 1$, a structured RNA (stRNA) in nanomolar concentrations. Also, the nanobody binds to various non-related stRNAs. However, it did not bind to single or doublestranded DNA/RNA or proteins with negative charges. The thermal unfolding/refolding processes were not affected by the presence or absence of nanobody. Therefore, nanobodies can be engineered to recognize stRNA epitopes. Nevertheless, their specificity should be improved in future works [104].

\section{Aptamers}

Aptamers are single-stranded nucleic acids (DNA/RNA) with high specificity and affinity to targets. In other words, they are nucleic acid analogs of antibodies but with better tissue penetration and transport and lower immunogenicity [105]. They act through three-dimensional structures, recognize secondary structures of lncRNAs, and interfere with RNA-protein interactions [105].

Systematic evolution of ligands by exponential enrichment (SELEX) is used to recognize and expand aptamers in vitro with the possibility of incorporating modified nucleic acids to produce nuclease resistant RNA aptamers [18].

\section{RNA decoy}

RNA decoys could be generated as imitators of lncRNAs and act through attachment to proteins and thus sequester proteins. They may function as an approach to disrupt the creation of functional lncRNA-RBP complexes. Scientists designed an anti-HIV decoy that targets the viral protein, Tat. It has (TAR) RNA hairpin and binds to Tat protein. This decoy localizes in the nucleolus whereas natural TAR RNA is located in the nucleus [106].

\section{LncRNA regulatory elements or expression patterns}

The gene of diphtheria toxin-A beside the H19 promoter was integrated into a double-stranded DNA plasmid BC819 (DTA-H19) in overexpressed H19 tumor cells. It was injected to intratumoral regions of various cancer types where reduction of tumor size was reported [107].

\section{Chemical modifications}

RNA is a dramatically unstable molecule and has poor pharmacological properties due to the presence of various endogenous ribonucleases. RNA has a negative charge and is hydrophilic. Besides, the $2^{\prime}-\mathrm{OH}$ group of ribose sugar makes it catalytically active. Therefore, chemical modification of RNA-based therapeutics is necessary to increase their stability without affecting biological activity [52]. (2'-OH) group of the ribose can be replaced by $2^{\prime}$-methoxy $\left(2^{\prime}\right.$-OMe), $2^{\prime}$-methoxyethoxy (2'-MOE), 2'-4'-O-methylene Bridge, locked nucleic 
acid (LNA), and 2'-fluoro (2'-F) to improve the pharmacological potential of siRNAs and ASOs [52] (Fig. 4).

In ASOs, the 2'-MOE-modified oligonucleotides are more stable in the serum and have higher RNA affinity compared with the 2'-OMe-modified analogs [108]. (2'$\mathrm{OMe}$ )-modified ASOs show increased stability against nucleases and high affinity with RNA compared to unmodified oligonucleotides. However, they are still sensitive to serum nucleases [109]. To avoid this limitation, 2'-OMe was modified along the whole chain, and to reduce the degradation by exonucleases short phosphorothioate fragments replaced $3{ }^{\prime}$ - and $5^{\prime}$-ends. Also, the hydrophobicity of ASOs increased with cholesterol moiety at the 3 '-end of the chain [110]. The 2'-F group increases nucleotide's affinity to the target RNA [111].

LNA is a class of bicyclic RNA analogs in which the $2^{\prime}-\mathrm{O}$ and 4'-C atoms are connected by a methylene linkage so that the furanose ring of the ribose sugar is chemically locked, resulting in higher thermal stability and the highest RNA affinity among typical ASOs $[62,112]$ (Fig. 4). The LNA strategy is also recruited to produce highly stable aptamers [113].

Phosphorothioate group forms when sulfur substitutes for non-binding oxygen atom of the phosphate group in a nucleotide, to enhance both their stability and hydrophobicity [114] (Fig. 4). It is used in the synthesis of ASOs and less often with aptamers and siRNAs [115].

Chemical modifications in the antisense strand of siRNAs are restricted to one or two internal nucleotides including 2'-OMe nucleotide substitutions and at the 3 'end. Phosphorothioate internucleotide linkages are exerted to improve the resistance of the siRNAs to nucleases. In the sense strand, more internal nucleotides can tolerate the 2'-OMe nucleotide substitutions so that siRNA remains functional within RISC. Such chemical modifications improve target cell penetration of siRNAs and assist their metabolic stability $[61,116]$. Unmodified siRNAs poorly uptake into target cells and organs and are rapidly degraded by nucleases that circulate in the blood [117].

The application of these strategies depends on the nature of the target. siRNAs effectively target lncRNAs in the cytoplasm [118]; however, successful silencing of IncRNAs by siRNAs has been reported irrespective of their intracellular location [119]. siRNAs are not as effective as ASOs and ribozymes in targeting secondary structures of lncRNAs [30, 120-122]. ASOs are more reliable for silencing highly expressed lncRNAs, which localize in the cell nuclei [123]. ASOs are less immunogenic and their small sizes let them enter the nucleus easier compared to double-stranded siRNAs [124, 125]. Besides, ASOs have higher specificity and fewer offtarget effects [52]. However, ASOs have shown off-target effects and difficulties in cellular uptake [30, 120-122].
Ribozymes exhibit less off-target effects since they are sensitive to single nucleotide mismatches [126]. In some cases, ASOs are preferable to small molecules owing to their specificity and ability to impair correct folding of lncRNAs [43].

\section{Approaches for systemic delivery of therapeutics}

The targeting strategies will be successful if they can be delivered to the right target organs or cells with adequate efficacy and safety. ASOs can be taken up freely by cells in vivo. However, efficient delivery to the target tissue is a major limitation of their use. Also, they have very long half-lives when entering cells, i.e., from 2-4 weeks in the liver [127] to $4-6$ months in the central nervous system (CNS) [128]. Systemically delivered ASOs exhibit rapid clearance from the blood and accumulate in the liver and kidney [129]. Other materials exploit delivery vehicles [30].

Liposomes are mostly used for nucleic acid delivery among lipid-based vectors. In a mouse model of ovarian cancer, the upregulated IncRNA ceruloplasmin (NRCP) was silenced using a phosphocholine derived, 1,2-dioleoyl-sn-glycero-3-phosphocholine (DOPC) nanoliposome containing siRNA. Substantial reduction of tumor growth and increased sensitivity to cisplatin was observed [130]. Polymeric vectors have low immunogenicity or toxicity, whose surfaces are manipulated to increase stability, tissue specificity, and cellular uptake [52]. As an example, dendrimers are utilized to deliver siRNAs. In lung cancer, a delivery platform comprising modified poly amidoamine (PAMAM) with polyethylene glycol (10C PEG) and 10 bromodecanoic acids to improve transfection efficiency, an aptamer for targeting nucleolin ligand on target cancer cells and shRNA plasmid for knockdown of B-cell lymphoma-extra large protein (Bcl-xL) were constructed. Modified vector markedly improved the transfection efficiency via covalent or non-covalent aptamer binding compared to the non-targeted vector [131]. Genetically engineered adenovirus, adeno-associated virus (AAV), retrovirus, or herpes simplex virus have been used for targeted delivery of RNA [132, 133]. Viral vectors show efficacy in delivering shRNAs in vivo and ex vivo. They suppress targeted RNAs stably and specifically. Using lentiviral frame plasmids as vectors against HOTAIR prevented proliferation and invasion of endometrial carcinoma cells in vitro and in vivo [134]. Efficient gene knockdown has been achieved via the fusion of aptamer to siRNA (aptamerguided RNAi). This strategy allows the delivery of siRNAs through receptor-mediated endocytosis for cellspecific targeting. The production on large scales with high purity and unlimited targeting of any gene in any cell type is the advantage of this approach. Linking aptamers with nanoparticles have also been exploited to 
increased cellular uptake and retention of drugs in cancer cells and target cells selectively [135]. In a mouse model of pancreatic cancer, engineered exosomes from normal fibroblast-like mesenchymal cells were utilized to deliver siRNA or shRNA against oncogenic $K$ RasG12D (K-Ras genes substitution-missense, position $12, G \Rightarrow D$ ). This suppression led to increased overall survival and inhibited tumor formation [136]. LncRNAs within exosomes remained functional when presented to target cells. Thus, they are appropriate to retrieve the expression of tumor-suppressive lncRNAs in tumor cells [137].

\section{Challenges in therapeutic targeting of IncRNAs}

Functional assessment and in vivo validation of therapeutics are challenging. The expression of human lncRNA should be evaluated in model animals which needs recognizing complex interactions between lncRNA and target genes and proteins [138]. However, lncRNAs are poorly conserved across the species. Many human lncRNAs could not be found in mice $[139,140]$ and a few orthologous lncRNAs were identified among humans and mouse [53]. Producing engineered mouse models with larger human genome segments or entire chromosomes or the exchange of mouse genome proteins can be beneficial [141].

Sometimes, it is difficult to gain consistent results while studying lncRNAs. Researchers demonstrated that MALAT1 involved in the regulation of alternative splicing in human Hella cells [142]. Although, concerning another study repression of MALAT1 in cultured cells or mice did not alter total splicing and phosphorylation of serine and arginine-rich (SR) proteins [143]. Furthermore, the normal phenotype was observed in defective Neat-1, H19, and MALAT1 mice [140]. However, in some cell lines, knockdown of MALAT1 led to apoptosis or cell cycle arrest [144]. Thus, high-throughput functional analysis is required for precise determination of molecular mechanisms of lncRNAs actions. CRISPRCas9 genome editing technology might be a strong tool for functional screens and the determination of oncolncRNAs, therapeutic targets, and drug resistance [145].

Long ncRNAs have tumor-specific expression patterns although differential lncRNA expression patterns were reported in some cases. Cancer heterogeneity may be causative so that a detailed analysis of cancer tissue may be more accurate compared to bulk tissue examination. Since lncRNAs are highly subjected to alternative splicing, we may lose a transcript isoform of lncRNAs by a general assessment of tumor tissue [53]. In situ hybridization of fluorescent RNA (FISH) to fresh-frozen or fixed tumor specimens [146] as well as single-cell RNA-seq [147, 148] might be a solution to this problem [53].
Toxicity and off-target effects are other limitations. Sugar modifications to give a high affinity to nucleic acids cause increased off-target cleavage of ASOs and siRNAs [148-150]. This is because in this case, 1-2 mismatches are tolerable and hybridization can take place in shorter regions of homology [151]. Phosphorothioated oligonucleotides demonstrated pro-inflammatory properties [152]. The transfection of cultured HeLa cells with 5-10-5 gapmer phosphorothioate-antisense oligonucleotides (PS-ASO) which undergo 2'-F nucleoside modifications (2'-F PS-ASO) caused DNA damage and cell death $[152,153]$. It randomly bound to cellular proteins with greater affinity than that of PS-ASOs containing 2'MOE or constrained-ethyl-bicyclic-nucleic-acid (cEt) modifications [153, 154]. Remarkable loss of RNase H1 activity will occur even with a single nucleotide mismatch in the cleavage site, three or more mismatches result in complete loss of activity $[155,156]$. Bioinformatics can help to predict some nonspecific hybridization to reduce off-target oligonucleotides base pairing. However, only $10-50 \%$ of the designed ASOs for gene silencing decreases the expression of the target [157]. RNA deep sequencing approaches (RNAseq) may contribute to eliminating off-target effects of oligonucleotides; however, they could not prepare quantitative information [158].

\section{Conclusions}

Long non-coding RNAs play key roles in cellular physiology, development, and disease states including cancer. Thus, they have an appealing potential to be therapeutic targets and drugs in cancer treatment. Nevertheless, the experience with therapeutic targeting of lncRNAs is limited. Most of the mentioned targeting strategies and delivery systems have been examined on mRNA and microRNAs. Only one clinical trial (www.clinicaltrials. gov, NCT02641847) [18] involving lncRNAs has been reported. The obstacles to the development of lncRNAs targeting therapeutics should be precisely explored. Bioinformatics, comprehensive databases, and highthroughput technologies might help establish a deep understanding of lncRNAs localization, structures, functional motifs, mechanisms of action, and interrelations with other biological molecules. The extensive functional screen is required to identify appropriate lncRNAs as therapeutic targets. Also, it is essential to study the exact features of modified oligonucleotides to avoid toxicity and produce efficient and safe drugs.

\footnotetext{
Abbreviations

(CC) cells: Cervical cancer cells; (CRISPR)/Cas9 system: Clustered regularly interspaced short palindromic repeats; "DWH": $(D=A / U / G, W=A / U$, and $H$ = A/U/C) sequence; 2'-F: 2'-Fluoro; 2'-MOE: 2'-Methoxyethoxy; 2'-OMe: 2'Methoxy; 3'-UTR: 3' Untranslated region; AAV: Adeno-associated virus; ANRIL: Antisense non-coding RNA in the INK4 locus; antagoNAT: Antagonist to NATs; ASOs: Antisense oligonucleotides; ATF5: Activating transcription
} 
factor 5; BANCR: BRAF-activated noncoding RNA; BCl-xL protein: B cell lymphoma-extra large protein; BDNF: Brain-derived neurotrophic factor; BDNF-AS: Brain-derived neurotrophic factor antisense; B-Myb: Myb-related protein B; BRAF: V-Raf murine sarcoma viral oncogene homolog B1; CAMP: Cyclic adenosine monophosphate; CD58: Lymphocyte functionassociated antigen 3; cEt: Constrained-ethyl-bicyclic-nucleic-acid; CHART: Capture hybridization analysis of RNA targets; CNS: Central nervous system; CRISPRi: CRISPR interference; dCas9: Catalytically dead Cas9; DG (m6A/A) CH motifs: ( $D=A, G$, or $U ; H=A, C$, or $U$ ) sequence of RNAs; DLK1: Delta like non-canonical notch ligand 1; DOPC: 1,2-Dioleoyl-sn-glycero3-phosphocholine; dsRNA: Double-stranded RNA; EMT: Epithelial-tomesenchymal transition; ENE: Stability element for nuclear expression; eRNAs: Enhancer RNAs; esi-RNA: Endoribonuclease-made siRNA EZH2: Enhancer of zeste homolog 2; FIRRE: Functional intergenic repeating RNA element; FISH: Fluorescence in situ hybridization; G2/M: Second growth phase (G2 phase)/mitosis (M phase); GAS5: Growth arrest specific 5; gRNA: Guide RNA; GWA: Genome-wide association; H19: Long noncoding RNA of H19 gene; H3K27me3: Tri-methylation at the 27th lysine residue of the histone $\mathrm{H} 3$ protein; H3K4: Histone $\mathrm{H} 3$ lysine 4 demethylation; HcAbs: Camelid heavy-chain antibodies; HHRz: The hammerhead ribozyme; HiTS-RAP: High-throughput sequencing-RNA affinity profiling; HIV: The human immunodeficiency viruses; HOTAIR: HOX transcript antisense RNA; HOX genes: Homeobox genes; KRAB: Kruppel-associated box; K-Ras G12D: KRas genes substitution - missense, position 12, G $\rightarrow$ D; LINC-PINT: Long intergenic non-protein coding RNA, P53 induced transcript; LMX1A: Transcription factor LIM homeobox transcription factor 1 alpha; LNAGapmeRs: Locked nucleic acid GapmeRs; LncRNA: Long non-coding RNA; LSD1: Lysine-specific histone demethylase 1A; m6A: $N^{6}$-methyladenosine; MALAT1: Metastasis-associated lung adenocarcinoma transcript 1; MEG3: Maternally expressed, imprinted long non-coding RNA; miRNAs: microRNA; mRNA: Messenger RNA; MXI1: Max-interacting protein 1; NATs: Natural antisense transcripts; NBAT-1: Neuroblastoma-associated transcript-1; N-BLR: Novel pyk-reg-90-containing InCRNA; NCAM1: Neural cell adhesion molecule1; NEAT1: Nuclear-enriched abundant transcript 1; NLRC5: NLR family, CARD domain containing 5; NRCP: IncRNA ceruloplasmin; NSPC1: Polycomb group RING finger protein 1; OMe/LNA: 2'-O-methyl/locked nucleic acid; p53: Tumor suppressor p53; PAMAM: Poly amidoamine; PEG: Polyethylene glycol; PRC2: Polycomb repressive complex 2; PRKCE: Protein kinase C epsilon; PS-ASOs: Phosphorothioate-antisense oligonucleotides; RAP: RNA affinity purification; RBP: RNA-binding proteins; RDE: RNA destabilizing elements; RISC: RNA-induced silencing complex; RNAseq: RNA sequencing; RNAi: RNA interference; RNA-MaP: RNA on a massively parallel array; SCAMP1: Secretory carrier membrane protein 1;

SChLAP1: Second chromosome locus associated with prostate-1;

SELEX: Systematic evolution of ligands by exponential enrichment; sgRNAs: Single guide RNA; siRNAs: Small interfering RNA; shRNA: Short hairpin RNA; Snail2: Zinc finger protein SNAI2; SNALP: Stable nucleic acid lipid particle; snRNAs: Small nuclear RNA; SOX2OT: SOX2 overlapping transcript; SR proteins: Serine and arginine-rich proteins; stRNAs: Structured RNAs; SWI/SNF: SWItch/Sucrose Non-Fermentable, also known as BRG1/BRMassociated factor (BAF) chromatin modifier family complex; TALENs: Transcription activator-like effector nucleases; TAR: Trans-activation responsive element; Tat: Trans-activator of transcription; TF: Transcription factor; TGF-b: Transforming growth factor-b; tRNAs: Transfer ribonucleic acid RNA; U87: Primary glioblastoma cell line; VH: Human immunoglobulin heavychain-variable region gene; VMC10: A deoxyribozyme; Wnt: Wingless signaling transduction pathway; XIST: X-inactive specific transcript; ZFNs: Zinc finger nucleases; ZO-1: Zonula occludens-1 ZO-1 or Tight junction protein-1

\section{Acknowledgements}

Not applicable

\section{Author's contributions}

The author drafted, revised, read, and approved the final manuscript.

\section{Funding}

Not applicable

Availability of data and materials

Not applicable
Ethics approval and consent to participate

Not applicable

\section{Consent for publication}

Not applicable

\section{Competing interests}

The author discloses no potential conflicts of interest.

Received: 17 February 2020 Accepted: 12 June 2020

Published online: 28 August 2020

\section{References}

1. Novikova IV, Hennelly SP, Sanbonmatsu KY (2013) Tackling structures of long noncoding RNAs. Int J Mol Sci 14(12):23672-23684

2. Mercer TR, Mattick JS (2013) Structure and function of long noncoding RNAs in epigenetic regulation. Nat Struct Mol Biol 20(3):300-307

3. Mercer TR, Dinger ME, Mattick JS (2009) Long non-coding RNAs: insights into functions. Nat Rev Genet 10(3):155-159

4. Geisler S, Coller J (2013) RNA in unexpected places: long non-coding RNA functions in diverse cellular contexts. Nat Rev Mol Cell Biol 14(11):699-712

5. Wang X, Song X, Glass CK, Rosenfeld MG (2011) The long arm of long noncoding RNAs: roles as sensors regulating gene transcriptional programs. Cold Spring Harb Perspect Biol 3(1):a003756

6. Tsai MC, Manor O, Wan Y, Mosammaparast N, Wang JK, Lan F, Shi Y, Segal E, Chang HY (2010) Long noncoding RNA as modular scaffold of histone modification complexes. Science (New York, NY) 329(5992):689-693

7. Lee JT (2010) The $X$ as model for RNA's niche in epigenomic regulation. Cold Spring Harb Perspect Biol 2(9):a003749

8. Bernard D, Prasanth KV, Tripathi V, Colasse S, Nakamura T, Xuan Z, Zhang MQ, Sedel F, Jourdren L, Coulpier F, Triller A, Spector DL, Bessis A (2010) A long nuclear-retained non-coding RNA regulates synaptogenesis by modulating gene expression. EMBO J 29(18):3082-3093

9. Wang D, Garcia-Bassets I, Benner C, Li W, Su X, Zhou Y, Qiu J, Liu W, Kaikkonen MU, Ohgi KA, Glass CK, Rosenfeld MG, Fu XD (2011) Reprogramming transcription by distinct classes of enhancers functionally defined by eRNA. Nature 474(7351):390-394

10. Pontier DB, Gribnau J (2011) Xist regulation and function explored. Hum Genet 130(2):223-236

11. Hindorff LA, Sethupathy P, Junkins HA, Ramos EM, Mehta JP, Collins FS, Manolio TA (2009) Potential etiologic and functional implications of genome-wide association loci for human diseases and traits. Proc Natl Acad Sci U S A 106(23):9362-9367

12. Akhade VS, Pal D, Kanduri C (2017) Long noncoding RNA: genome organization and mechanism of action. Adv Exp Med Biol 1008:47-74

13. Hanahan D, Weinberg RA (2000) The hallmarks of cancer. Cell 100(1):57-70

14. Gutschner T, Diederichs S (2012) The hallmarks of cancer. RNA Biol 9(6):703719

15. Bartonicek N, Maag JLV, Dinger ME (2016) Long noncoding RNAs in cancer: mechanisms of action and technological advancements. Mol Cancer 15(1): 43

16. Arun G, Diermeier SD, Spector DL (2018) Therapeutic targeting of long noncoding RNAs in cancer. Trends Mol Med 24(3):257-277

17. Huarte M (2015) The emerging role of IncRNAs in cancer. Nat Med 21:1253

18. Renganathan A, Felley-Bosco E (2017) Long noncoding RNAs in cancer and therapeutic potential. Adv Exp Med Biol 1008:199-222

19. Li Y, Wang Z, Wang Y, Zhao Z, Zhang J, Lu J, Xu J, Li X (2016) Identification and characterization of IncRNA mediated transcriptional dysregulation dictates IncRNA roles in glioblastoma. Oncotarget 7(29):45027-45041

20. Tripathi V, Shen Z, Chakraborty A, Giri S, Freier SM, Wu X, Zhang Y, Gorospe M, Prasanth SG, Lal A, Prasanth KV (2013) Long noncoding RNA MALAT1 controls cell cycle progression by regulating the expression of oncogenic transcription factor B-MYB. PLoS Genet 9(3):e1003368

21. Hajjari M, Salavaty A (2015) HOTAIR: an oncogenic long non-coding RNA in different cancers. Cancer Biol Med 12(1):1-9

22. Bhan A, Mandal SS (2015) LncRNA HOTAIR: a master regulator of chromatin dynamics and cancer. Biochim Biophys Acta 1856(1):151-164

23. Nakayama I, Shibazaki M, Yashima-Abo A, Miura F, Sugiyama T, Masuda T, Maesawa C (2013) Loss of HOXD10 expression induced by upregulation of miR-10b accelerates the migration and invasion activities of ovarian cancer cells. Int J Oncol 43(1):63-71 
24. Milhem MM, Knutson T, Yang S, Zhu D, Wang X, Leslie KK, Meng X (2011) Correlation of MTDH/AEG-1 and HOTAIR expression with metastasis and response to treatment in sarcoma patients. J Cancer Sci Ther S5(4)

25. Ding C, Cheng S, Yang Z, Lv Z, Xiao H, Du C, Peng C, Xie H, Zhou L, Wu J, Zheng S (2014) Long non-coding RNA HOTAIR promotes cell migration and invasion via down-regulation of RNA binding motif protein 38 in hepatocellular carcinoma cells. Int J Mol Sci 15(3):4060-4076

26. Kogo R, Shimamura T, Mimori K, Kawahara K, Imoto S, Sudo T, Tanaka F, Shibata K, Suzuki A, Komune S, Miyano S, Mori M (2011) Long noncoding RNA HOTAIR regulates polycomb-dependent chromatin modification and is associated with poor prognosis in colorectal cancers. Cancer Res 71(20): 6320-6326

27. Kim K, Jutooru I, Chadalapaka G, Johnson G, Frank J, Burghardt R, Kim S, Safe $S$ (2013) HOTAIR is a negative prognostic factor and exhibits prooncogenic activity in pancreatic cancer. Oncogene 32(13):1616-1625

28. Xu F, Zhang J (2017) Long non-coding RNA HOTAIR functions as miRNA sponge to promote the epithelial to mesenchymal transition in esophageal cancer. Biomed Pharmacother 90:888-896

29. Tripathi V, Ellis JD, Shen Z, Song DY, Pan Q, Watt AT, Freier SM, Bennett CF, Sharma A, Bubulya PA, Blencowe BJ, Prasanth SG, Prasanth KV (2010) The nuclear-retained noncoding RNA MALAT1 regulates alternative splicing by modulating SR splicing factor phosphorylation. Mol Cell 39(6):925-938

30. Gutschner T, Hammerle M, Eissmann M, Hsu J, Kim Y, Hung G, Revenko A, Arun G, Stentrup M, Gross M, Zornig M, MacLeod AR, Spector DL, Diederichs S (2013) The noncoding RNA MALAT1 is a critical regulator of the metastasis phenotype of lung cancer cells. Cancer Res 73(3):1180-1189

31. Schmidt LH, Spieker T, Koschmieder S, Schaffers S, Humberg J, Jungen D, Bulk E, Hascher A, Wittmer D, Marra A, Hillejan L, Wiebe K, Berdel WE, Wiewrodt R, Muller-Tidow C (2011) The long noncoding MALAT-1 RNA indicates a poor prognosis in non-small cell lung cancer and induces migration and tumor growth. J Thorac Oncol 6(12):1984-1992

32. Ying L, Chen Q, Wang Y, Zhou Z, Huang Y, Qiu F (2012) Upregulated MALAT-1 contributes to bladder cancer cell migration by inducing epithelial-to-mesenchymal transition. Mol BioSyst 8(9):2289-2294

33. Hutchinson JN, Ensminger AW, Clemson CM, Lynch CR, Lawrence JB, Chess A (2007) A screen for nuclear transcripts identifies two linked noncoding RNAs associated with SC35 splicing domains. BMC Genomics 8:39

34. Marín-Béjar O, Marchese FP, Athie A, Sánchez Y, González J, Segura V, Huang L, Moreno I, Navarro A, Monzó M, García-Foncillas J, Rinn JL, Guo S, Huarte M (2013) PintlincRNA connects the p53 pathway with epigenetic silencing by the Polycomb repressive complex 2. Genome Biol 14(9):R104

35. Marín-Béjar O, Mas AM, González J, Martinez D, Athie A, Morales X, Galduroz M, Raimondi I, Grossi E, Guo S, Rouzaut A, Ulitsky I, Huarte M (2017) The human IncRNA LINC-PINT inhibits tumor cell invasion through a highly conserved sequence element. Genome Biol 18(1):202

36. Miyoshi N, Wagatsuma H, Wakana S, Shiroishi T, Nomura M, Aisaka K, Kohda T, Surani MA, Kaneko-Ishino T, Ishino F (2000) Identification of an imprinted gene, Meg3/Gtl2 and its human homologue MEG3, first mapped on mouse distal chromosome 12 and human chromosome 14q. Genes Cells 5(3):211220

37. Zhou Y, Zhang X, Klibanski A (2012) MEG3 noncoding RNA: a tumor suppressor. J Mol Endocrinol 48(3):R45-R53

38. Wang $P$, Chen D, Ma H, Li Y (2017) LncRNA MEG3 enhances cisplatin sensitivity in non-small cell lung cancer by regulating miR-21-5p/SOX7 axis. OncoTargets Ther 10:5137-5149

39. Wu Z, He Y, Li D, Fang X, Shang T, Zhang H, Zheng X (2017) Long noncoding RNA MEG3 suppressed endothelial cell proliferation and migration through regulating miR-21. Am J Transl Res 9(7):3326-3335

40. Benetatos L, Vartholomatos G, Hatzimichael E (2011) MEG3 imprinted gene contribution in tumorigenesis. Int J Cancer 129(4):773-779

41. Mondal T, Subhash S, Vaid R, Enroth S, Uday S, Reinius B, Mitra S, Mohammed A, James AR, Hoberg E, Moustakas A, Gyllensten U, Jones SJ, Gustafsson CM, Sims AH, Westerlund F, Gorab E, Kanduri C (2015) MEG3 long noncoding RNA regulates the TGF-beta pathway genes through formation of RNA-DNA triplex structures. Nat Commun 6:7743

42. Zhou Y, Zhong Y, Wang Y, Zhang X, Batista DL, Gejman R, Ansell PJ, Zhao J, Weng C, Klibanski A (2007) Activation of p53 by MEG3 non-coding RNA. J Biol Chem 282(34):24731-24742

43. Chandra Gupta S, Nandan Tripathi Y (2017) Potential of long non-coding RNAs in cancer patients: from biomarkers to therapeutic targets. Int J Cancer 140(9):1955-1967
44. Fu X, Ravindranath L, Tran N, Petrovics G, Srivastava S (2006) Regulation of apoptosis by a prostate-specific and prostate cancer-associated noncoding gene, PCGEM1. DNA Cell Biol 25(3):135-141

45. Kurian L, Aguirre A, Sancho-Martinez I, Benner C, Hishida T, Nguyen TB, Reddy P, Nivet E, Krause MN, Nelles DA, Esteban CR, Campistol JM, Yeo GW, Belmonte JCl (2015) Identification of novel long noncoding RNAs underlying vertebrate cardiovascular development. Circulation 131(14): 1278-1290

46. Casero D, Sandoval S, Seet CS, Scholes J, Zhu Y, Ha VL, Luong A, Parekh C, Crooks GM (2015) Long non-coding RNA profiling of human lymphoid progenitor cells reveals transcriptional divergence of B cell and T cell lineages. Nat Immunol 16(12):1282-1291

47. Sanchez Y, Huarte M (2013) Long non-coding RNAs: challenges for diagnosis and therapies. Nucleic Acid Ther 23(1):15-20

48. Lee GL, Dobi A, Srivastava S (2011) Diagnostic performance of the PCA3 urine test. Nat Rev Urol 8(3):123-124

49. Sartori DA, Chan DW (2014) Biomarkers in prostate cancer: what's new? Curr Opin Oncol 26(3):259-264

50. Bussemakers MJ, van Bokhoven A, Verhaegh GW, Smit FP, Karthaus HF, Schalken JA, Debruyne FM, Ru N, Isaacs WB (1999) DD3: a new prostatespecific gene, highly overexpressed in prostate cancer. Cancer Res 59(23): 5975-5979

51. de Kok JB, Verhaegh GW, Roelofs RW, Hessels D, Kiemeney LA, Aalders TW Swinkels DW, Schalken JA (2002) DD3(PCA3), a very sensitive and specific marker to detect prostate tumors. Cancer Res 62(9):2695-2698

52. Slaby O, Laga R, Sedlacek O (2017) Therapeutic targeting of non-coding RNAs in cancer. Biochem J 474(24):4219-4251

53. Gutschner T, Richtig G, Haemmerle M, Pichler M (2018) From biomarkers to therapeutic targets-the promises and perils of long non-coding RNAs in cancer. Cancer Metastasis Rev 37(1):83-105

54. Walder RY, Walder JA (1988) Role of RNase $\mathrm{H}$ in hybrid-arrested translation by antisense oligonucleotides. Proc Natl Acad Sci U S A 85(14):5011-5015

55. Chiriboga CA (2017) Nusinersen for the treatment of spinal muscular atrophy. Expert Rev Neurother 17(10):955-962

56. Jaschinski F, Rothhammer T, Jachimczak P, Seitz C, Schneider A, Schlingensiepen KH (2011) The antisense oligonucleotide trabedersen (AP 12009) for the targeted inhibition of TGF-beta2. Curr Pharm Biotechnol 12(12):2203-2213

57. Kurreck J, Wyszko E, Gillen C, Erdmann VA (2002) Design of antisense oligonucleotides stabilized by locked nucleic acids. Nucleic Acids Res 30(9): 1911-1918

58. Beletskii A, Hong YK, Pehrson J, Egholm M, Strauss WM (2001) PNA interference mapping demonstrates functional domains in the noncoding RNA Xist. Proc Natl Acad Sci U S A 98(16):9215-9220

59. Sarma K, Levasseur P, Aristarkhov A, Lee JT (2010) Locked nucleic acids (LNAs) reveal sequence requirements and kinetics of Xist RNA localization to the X chromosome. Proc Natl Acad Sci U S A 107(51):22196-22201

60. Modarresi F, Faghihi MA, Lopez-Toledano MA, Fatemi RP, Magistri M, Brothers SP, van der Brug MP, Wahlestedt C (2012) Inhibition of natural antisense transcripts in vivo results in gene-specific transcriptional upregulation. Nat Biotechnol 30(5):453-459

61. Kole R, Krainer AR, Altman S (2012) RNA therapeutics: beyond RNA interference and antisense oligonucleotides. Nat Rev Drug Discov 11(2):125140

62. Ivanova G, Reigadas S, Ittig D, Arzumanov A, Andreola ML, Leumann C, Toulme JJ, Gait MJ (2007) Tricyclo-DNA containing oligonucleotides as steric block inhibitors of human immunodeficiency virus type 1 tat-dependent trans-activation and HIV-1 infectivity. Oligonucleotides 17(1):54-65

63. Martinez J, Patkaniowska A, Urlaub H, Luhrmann R, Tuschl T (2002) Singlestranded antisense siRNAs guide target RNA cleavage in RNAi. Cell 110(5): 563-574

64. Buchholz F, Kittler R, Slabicki M, Theis M (2006) Enzymatically prepared RNAi libraries. Nat Methods 3(9):696-700

65. Prensner JR, lyer MK, Sahu A, Asangani IA, Cao Q, Patel L, Vergara IA, Davicioni E, Erho N, Ghadessi M, Jenkins RB, Triche TJ, Malik R, Bedenis R, McGregor N, Ma T, Chen W, Han S, Jing X, Cao X, Wang X, Chandler B, Yan W, Siddiqui J, Kunju LP, Dhanasekaran SM, Pienta KJ, Feng FY, Chinnaiyan AM (2013) The long noncoding RNA SChLAP1 promotes aggressive prostate cancer and antagonizes the SWI/SNF complex. Nat Genet 45(11):1392-1398

66. Sun R, Qin C, Jiang B, Fang S, Pan X, Peng L, Liu Z, Li W, Li Y, Li G (2016) Down-regulation of MALAT1 inhibits cervical cancer cell invasion and 
metastasis by inhibition of epithelial-mesenchymal transition. Mol BioSyst 12(3):952-962

67. Youn YH, Byun HJ, Yoon JH, Park CH, Lee SK (2019) Long Noncoding RNA $\mathrm{N}-\mathrm{BLR}$ Upregulates the migration and invasion of gastric adenocarcinoma. Gu Liver 13(4):421-429

68. Zong Z, Song Y, Xue Y, Ruan X, Liu X, Yang C, Zheng J, Cao S, Li Z, Liu Y (2019) Knockdown of LncRNA SCAMP1 suppressed malignant biological behaviours of glioma cells via modulating miR-499a-5p/LMX1A/NLRC5 pathway. J Cell Mol Med 23(8):5048-5062

69. Liang Z, Wang Y, Li H, Sun Y, Gong Y (2019) IncRNAs combine and crosstalk with NSPC1 in ATRA-induced differentiation of U87 glioma cells. Oncol Lett 17(6):5821-5829

70. Faghihi MA, Kocerha J, Modarresi F, Engstrom PG, Chalk AM, Brothers SP, Koesema E, Laurent GS, Wahlestedt C (2010) RNAi screen indicates widespread biological function for human natural antisense transcripts. PLoS One 5(10)

71. Santoro SW, Joyce GF (1998) Mechanism and utility of an RNA-cleaving DNA enzyme. Biochemistry 37(38):13330-13342

72. Khachigian LM (2002) DNAzymes: cutting a path to a new class of therapeutics. Curr Opin Mol Ther 4(2):119-121

73. Silverman SK (2005) In vitro selection, characterization, and application of deoxyribozymes that cleave RNA. Nucleic Acids Res 33(19):6151-6163

74. Liu N, Parisien M, Dai Q, Zheng G, He C, Pan T (2013) Probing N6methyladenosine RNA modification status at single nucleotide resolution in mRNA and long noncoding RNA. Rna 19(12):1848-1856

75. Liu N, Dai Q, Zheng G, He C, Parisien M, Pan T (2015) N(6)-methyladenosinedependent RNA structural switches regulate RNA-protein interactions. Nature 518(7540):560-564

76. Sednev MV, Mykhailiuk V, Choudhury P, Halang J, Sloan KE, Bohnsack MT, Hobartner C (2018) N(6) -methyladenosine-sensitive RNA-cleaving deoxyribozymes. Angew Chem Int Ed Eng 57(46):15117-15121

77. Franzen S (2010) Expanding the catalytic repertoire of ribozymes and deoxyribozymes beyond RNA substrates. Curr Opin Mol Ther 12(2):223-232

78. Martick M, Scott WG (2006) Tertiary contacts distant from the active site prime a ribozyme for catalysis. Cell 126(2):309-320

79. Ruffner DE, Stormo GD, Uhlenbeck OC (1990) Sequence requirements of the hammerhead RNA self-cleavage reaction. Biochemistry 29(47):10695-10702

80. Kore AR, Vaish NK, Morris JA, Eckstein F (2000) In vitro evolution of the hammerhead ribozyme to a purine-specific ribozyme using mutagenic PCR with two nucleotide analogues. J Mol Biol 301(5):1113-1121

81. Eckstein F, Kore AR, Nakamaye KL (2001) In vitro selection of hammerhead ribozyme sequence variants. ChemBioChem 2(9):629-635

82. Liu G, Huang X, Pu Q, Zhao Y, Du F, Dong J, Cui X, Tang Z (2017) Recharacterization of hammerhead ribozymes as molecular tools for intermolecular RNA cleavage. Org Biomol Chem 15(21):4681-4685

83. Li Z, Rana TM (2014) Therapeutic targeting of microRNAs: current status and future challenges. Nat Rev Drug Discov 13:622

84. Gutschner T, Baas M, Diederichs S (2011) Noncoding RNA gene silencing through genomic integration of RNA destabilizing elements using zinc finger nucleases. Genome Res 21(11):1944-1954

85. Eissmann M, Gutschner T, Hammerle M, Gunther S, Caudron-Herger M, Gross M, Schirmacher P, Rippe K, Braun T, Zornig M, Diederichs S (2012) Loss of the abundant nuclear non-coding RNA MALAT1 is compatible with life and development. RNA Biol 9(8):1076-1087

86. Miller JC, Holmes MC, Wang J, Guschin DY, Lee Y-L, Rupniewski I, Beausejour CM, Waite AJ, Wang NS, Kim KA, Gregory PD, Pabo CO, Rebar EJ (2007) An improved zinc-finger nuclease architecture for highly specific genome editing. Nat Biotechnol 25(7):778-785

87. Han J, Zhang J, Chen L, Shen B, Zhou J, Hu B, Du Y, Tate PH, Huang X Zhang W (2014) Efficient in vivo deletion of a large imprinted IncRNA by CRISPR/Cas9. RNA Biol 11(7):829-835

88. Qi LS, Larson MH, Gilbert LA, Doudna JA, Weissman JS, Arkin AP, Lim WA (2013) Repurposing CRISPR as an RNA-guided platform for sequencespecific control of gene expression. Cell 152(5):1173-1183

89. Gillbert LA, Larson MH, Morsut L, Liu Z, Brar GA, Torres SE, Stern-Ginossar N, Brandman O, Whitehead EH, Doudna JA, Lim WA, Weissman JS, Qi LS (2013) CRISPR-mediated modular RNA-guided regulation of transcription in eukaryotes. Cell 154(2):442-451

90. Pedram Fatemi R, Salah-Uddin S, Modarresi F, Khoury N, Wahlestedt C, Faghihi MA (2015) Screening for small-molecule modulators of long noncoding RNA-protein interactions using AlphaScreen. J Biomol Screen 20(9):1132-1141
91. Simon MD, Wang Cl, Kharchenko PV, West JA, Chapman BA, Alekseyenko AA, Borowsky ML, Kuroda MI, Kingston RE (2011) The genomic binding sites of a noncoding RNA. Proc Natl Acad Sci U S A 108(51):20497-20502

92. West JA, Davis CP, Sunwoo H, Simon MD, Sadreyev RI, Wang PI, Tolstorukov MY, Kingston RE (2014) The long noncoding RNAs NEAT1 and MALAT1 bind active chromatin sites. Mol Cell 55(5):791-802

93. McHugh CA, Guttman M (2018) RAP-MS: A method to identify proteins that interact directly with a specific RNA molecule in cells. Methods Mol Biiol $1649: 473-488$

94. Fatemi RP, Velmeshev D, Faghihi MA (2014) De-repressing LncRNA-targeted genes to upregulate gene expression: focus on small molecule therapeutics. Mol Ther Nucleic Acids 3:e196

95. Tome JM, Ozer A, Pagano JM, Gheba D, Schroth GP, Lis JT (2014) Comprehensive analysis of RNA-protein interactions by high-throughput sequencing-RNA affinity profiling. Nat Methods 11(6):683-688

96. Rzuczek SG, Southern MR, Disney MD (2015) Studying a drug-like, RNAfocused small molecule library identifies compounds that inhibit RNA toxicity in myotonic dystrophy. ACS Chem Biol 10(12):2706-2715

97. Mehta A, Sonam S, Gouri I, Loharch S, Sharma DK, Parkesh R (2014) SMMRNA: a database of small molecule modulators of RNA. Nucleic Acids Res 42(Database issue):D132-D141

98. Tsai MC, Spitale RC, Chang HY (2011) Long intergenic noncoding RNAs: new links in cancer progression. Cancer Res 71(1):3-7

99. Tycowski KT, Shu MD, Steitz JA (2016) Myriad triple-helix-forming structures in the transposable element RNAs of plants and fungi. Cell Rep 15(6):12661276

100. Wilusz JE, JnBaptiste CK, Lu LY, Kuhn CD, Joshua-Tor L, Sharp PA (2012) A triple helix stabilizes the $3^{\prime}$ ends of long noncoding RNAs that lack poly(A) tails. Genes Dev 26(21):2392-2407

101. Brown JA, Bulkley D, Wang J, Valenstein ML, Yario TA, Steitz TA, Steitz JA (2014) Structural insights into the stabilization of MALAT1 noncoding RNA by a bipartite triple helix. Nat Struct Mol Biol 21(7):633-640

102. Abulwerdi FA, Xu W, Ageeli AA, Yonkunas MJ, Arun G, Nam H, Schneekloth JS Jr, Dayie TK, Spector D, Baird N, Le Grice SFJ (2019) Selective smallmolecule targeting of a triple helix encoded by the long noncoding RNA, MALAT1. ACS Chem Biol 14(2):223-235

103. Van Audenhove I, Gettemans J (2016) Nanobodies as versatile tools to understand, diagnose, visualize and treat cancer. EBioMedicine 8:40-48

104. Cawez F, Duray E, Hu Y, Vandenameele J, Romao E, Vincke C, Dumoulin M, Galleni M, Muyldermans S, Vandevenne M (2018) Combinatorial design of a nanobody that specifically targets structured RNAs. J Mol Biol 430(11):16521670

105. Watrin M, Von Pelchrzim F, Dausse E, Schroeder R, Toulme JJ (2009) In vitro selection of RNA aptamers derived from a genomic human library against the TAR RNA element of HIV-1. Biochemistry 48(26):6278-6284

106. Li MJ, Kim J, Li S, Zaia J, Yee JK, Anderson J, Akkina R, Rossi JJ (2005) Longterm inhibition of HIV-1 infection in primary hematopoietic cells by lentiviral vector delivery of a triple combination of anti-HIV shRNA, anti-CCR5 ribozyme, and a nucleolar-localizing TAR decoy. Mol Ther 12(5):900-909

107. Mizrahi A, Czerniak A, Levy T, Amiur S, Gallula J, Matouk I, Abu-lail R, Sorin V, Birman T, de Groot N, Hochberg A, Ohana P (2009) Development of targeted therapy for ovarian cancer mediated by a plasmid expressing diphtheria toxin under the control of $\mathrm{H} 19$ regulatory sequences. J Transl Med 7:69

108. Esau CC (2008) Inhibition of microRNA with antisense oligonucleotides. Methods 44(1):55-60

109. Meister $G$, Landthaler $M$, Dorsett $Y$, Tuschl $T$ (2004) Sequence-specific inhibition of microRNA- and siRNA-induced RNA silencing. Rna 10(3):544550

110. Krützfeldt J, Rajewsky N, Braich R, Rajeev KG, Tuschl T, Manoharan M, Stoffel M (2005) Silencing of microRNAs in vivo with 'antagomirs'. Nature 438(7068):685-689

111. Kawasaki AM, Casper MD, Freier SM, Lesnik EA, Zounes MC, Cummins LL, Gonzalez C, Cook PD (1993) Uniformly modified 2'-deoxy-2'-fluoro phosphorothioate oligonucleotides as nuclease-resistant antisense compounds with high affinity and specificity for RNA targets. J Med Chem 36(7):831-841

112. Elmén J, Lindow $M$, Schütz $S$, Lawrence $M$, Petri $A$, Obad $S$, Lindholm $M$, Hedtjärn M, Hansen HF, Berger U, Gullans S, Kearney P, Sarnow P, Straarup EM, Kauppinen S (2008) LNA-mediated microRNA silencing in non-human primates. Nature 452(7189):896-899 
113. Keefe AD, Pai S, Ellington A (2010) Aptamers as therapeutics. Nat Rev Drug Discov 9(7):537-550

114. Eckstein F (2014) Phosphorothioates, essential components of therapeutic oligonucleotides. Nucleic Acid Ther 24(6):374-387

115. Shukla S, Sumaria CS, Pradeepkumar PI (2010) Exploring chemical modifications for siRNA therapeutics: a structural and functional outlook. Chem Med Chem 5(3):328-349

116. Watts JK, Deleavey GF, Damha MJ (2008) Chemically modified siRNA: tools and applications. Drug Discov Today 13(19-20):842-855

117. Song E, Lee SK, Wang J, Ince N, Ouyang N, Min J, Chen J, Shankar P, Lieberman J (2003) RNA interference targeting Fas protects mice from fulminant hepatitis. Nat Med 9(3):347-351

118. Gagnon KT, Li L, Chu Y, Janowski BA, Corey DR (2014) RNAi factors are present and active in human cell nuclei. Cell Rep 6(1):211-221

119. Nobrega MA, Ovcharenko I, Afzal V, Rubin EM (2003) Scanning human gene deserts for long-range enhancers. Science (New York, NY) 302(5644):413

120. Kotake Y, Nakagawa T, Kitagawa K, Suzuki S, Liu N, Kitagawa M, Xiong Y (2011) Long non-coding RNA ANRIL is required for the PRC2 recruitment to and silencing of p15(INK4B) tumor suppressor gene. Oncogene 30(16):19561962

121. Lebo K, Niederer RO, Zappulla DC (2015) A second essential function of the Est1-binding arm of yeast telomerase RNA. Rna 21(5):862-876

122. Zappulla DC, Cech TR (2006) RNA as a flexible scaffold for proteins: yeast telomerase and beyond. Cold Spring Harb Symp Quant Biol 71:217-224

123. Lennox KA, Behlke MA (2016) Cellular localization of long non-coding RNAs affects silencing by RNAi more than by antisense oligonucleotides. Nucleic Acids Res 44(2):863-877

124. Robbins M, Judge A, MacLachlan I (2009) siRNA and innate immunity. Oligonucleotides 19(2):89-102

125. Jones NR, Pegues MA, McCrory MA, Singleton W, Bethune C, Baker BF, Norris DA, Crooke RM, Graham MJ, Szalai AJ (2012) A selective inhibitor of human C-reactive protein translation is efficacious in vitro and in C-reactive protein transgenic mice and humans. Mol Ther Nucleic Acids 1

126. Pavco PA, Bouhana KS, Gallegos AM, Agrawal A, Blanchard KS, Grimm SL, Jensen KL, Andrews LE, Wincott FE, Pitot PA, Tressler RJ, Cushman C, Reynolds MA, Parry TJ (2000) Antitumor and antimetastatic activity of ribozymes targeting the messenger RNA of vascular endothelial growth factor receptors. Clin Cancer Res 6(5):2094-2103

127. Geary RS, Norris D, Yu R, Bennett CF (2015) Pharmacokinetics, biodistribution and cell uptake of antisense oligonucleotides. Adv Drug Deliv Rev 87:46-51

128. Chiriboga CA, Swoboda KJ, Darras BT, lannaccone ST, Montes J, De Vivo DC, Norris DA, Bennett CF, Bishop KM (2016) Results from a phase 1 study of nusinersen (ISIS-SMNRx) in children with spinal muscular atrophy. Neurology 86(10):890-897

129. Scharner J, Qi S, Rigo F, Bennett CF, Krainer AR (2019) Delivery of GalNAc-conjugated splice-switching ASOs to non-hepatic cells through ectopic expression of asialoglycoprotein receptor. Mol Ther Nucleic Acids 16:313-325

130. Rupaimoole R, Lee J, Haemmerle M, Ling H, Previs RA, Pradeep S, Wu SY, Ivan C, Ferracin M, Dennison JB, Millward NMZ, Nagaraja AS, Gharpure KM, McGuire M, Sam N, Armaiz-Pena GN, Sadaoui NC, Rodriguez-Aguayo C, Calin GA, Drapkin Rl, Kovacs J, Mills GB, Zhang W, Lopez-Berestein G, Bhattacharya PK, Sood AK (2015) Long noncoding RNA ceruloplasmin promotes cancer growth by altering glycolysis. Cell Rep 13(11):2395-2402

131. Ayatollahi S, Salmasi Z, Hashemi M, Askarian S, Oskuee RK, Abnous K, Ramezani M (2017) Aptamer-targeted delivery of BCl-xL shRNA using alkyl modified PAMAM dendrimers into lung cancer cells. Int J Biochem Cell Biol 92:210-217

132. Couto LB, High KA (2010) Viral vector-mediated RNA interference. Curr Opin Pharmacol 10(5):534-542

133. Schott JW, Morgan M, Galla M, Schambach A (2016) Viral and synthetic RNA vector technologies and applications. Mol Ther 24(9):1513-1527

134. Huang J, Ke P, Guo L, Wang W, Tan H, Liang Y, Yao S (2014) Lentivirusmediated RNA interference targeting the long noncoding RNA HOTAIR inhibits proliferation and invasion of endometrial carcinoma cells in vitro and in vivo. Int J Gynecol Cancer 24(4):635-642

135. Xiang D, Zheng C, Zhou SF, Qiao S, Tran PH, Pu C, Li Y, Kong L, Kouzani AZ, Lin J, Liu K, Li L, Shigdar S, Duan W (2015) Superior performance of aptamer in tumor penetration over antibody: implication of aptamer-based theranostics in solid tumors. Theranostics 5(10):1083-1097
136. Kamerkar S, LeBleu VS, Sugimoto H, Yang S, Ruivo CF, Melo SA, Lee JJ, Kalluri R (2017) Exosomes facilitate therapeutic targeting of oncogenic KRAS in pancreatic cancer. Nature 546(7659):498-503

137. Takahashi K, Yan IK, Haga H, Patel T (2014) Modulation of hypoxia-signaling pathways by extracellular linc-RoR. J Cell Sci 127(Pt 7):1585-1594

138. Matsui M, Corey DR (2017) Non-coding RNAs as drug targets. Nat Rev Drug Discov 16(3):167-179

139. Necsulea A, Soumillon M, Warnefors M, Liechti A, Daish T, Zeller U, Baker JC, Grützner F, Kaessmann H (2014) The evolution of IncRNA repertoires and expression patterns in tetrapods. Nature 505:635

140. Lee JT (2012) Epigenetic regulation by long noncoding RNAs. Science 338(6113):1435-1439

141. Devoy A, Bunton-Stasyshyn RK, Tybulewicz VL, Smith AJ, Fisher EM (2011) Genomically humanized mice: technologies and promises. Nat Rev Genet 13(1):14-20

142. Tripathi V, Ellis JD, Shen Z, Song DY, Pan Q, Watt AT, Freier SM, Bennett CF, Sharma A, Bubulya PA, Blencowe BJ, Prasanth SG, Prasanth KV (2010) The Nuclear-Retained Noncoding RNA MALAT1 Regulates Alternative Splicing by Modulating SR Splicing Factor Phosphorylation. Mol cell 39(6):925-938

143. Zhang B, Arun G, Mao YS, Lazar Z, Hung G, Bhattacharjee G, Xiao X, Booth CJ, Wu J, Zhang C, Spector DL (2012) The IncRNA Malat1 is dispensable for mouse development but its transcription plays a cis-regulatory role in the adult. Cell Rep 2(1):111-123

144. Gutschner T, Hämmerle M, Diederichs S (2013) MALAT1 — a paradigm for long noncoding RNA function in cancer. J Mol Med 91(7):791-801

145. Esposito R, Bosch N, Lanzos A, Polidori T, Pulido-Quetglas C, Johnson R (2019) Hacking the cancer genome: profiling therapeutically actionable long non-coding RNAs using CRISPR-Cas9 screening. Cancer Cell 35(4):545-557

146. Soares RJ, Maglieri G, Gutschner T, Diederichs S, Lund AH, Nielsen BS, Holmstrom K (2018) Evaluation of fluorescence in situ hybridization techniques to study long non-coding RNA expression in cultured cells. Nucleic Acids Res 46(1):e4

147. Tirosh I, Izar B, Prakadan SM, Wadsworth MH, Treacy D, Trombetta JJ, Rotem A, Rodman C, Lian C, Murphy G, Fallahi-Sichani M, Dutton-Regester K, Lin J-R, Cohen O, Shah P, Lu D, Genshaft AS, Hughes TK, Ziegler CGK, Kazer SW, Gaillard A, Kolb KE, Villani A-C, Johannessen CM, Andreev AY, Van Allen EM, Bertagnolli M, Sorger PK, Sullivan RJ, Flaherty KT, Frederick DT, Jané-Valbuena J, Yoon CH, Rozenblatt-Rosen O, Shalek AK, Regev A, Garraway LA (2016) Dissecting the multicellular ecosystem of metastatic melanoma by single-cell RNA-seq. Science 352(6282):189-196

148. Chung W, Eum HH, Lee H-O, Lee K-M, Lee H-B, Kim K-T, Ryu HS, Kim S, Lee JE, Park YH, Kan Z, Han W, Park W-Y (2017) Single-cell RNA-seq enables comprehensive tumour and immune cell profiling in primary breast cancer. Nat Commun 8(1):15081

149. Kasuya T, Hori S, Watanabe A, Nakajima M, Gahara Y, Rokushima M, Yanagimoto T, Kugimiya A (2016) Ribonuclease H1-dependent hepatotoxicity caused by locked nucleic acid-modified gapmer antisense oligonucleotides. Sci Rep 6:30377

150. Burel SA, Hart CE, Cauntay P, Hsiao J, Machemer T, Katz M, Watt A, Bui HH Younis H, Sabripour M, Freier SM, Hung G, Dan A, Prakash TP, Seth PP, Swayze EE, Bennett CF, Crooke ST, Henry SP (2016) Hepatotoxicity of high affinity gapmer antisense oligonucleotides is mediated by RNase $\mathrm{H} 1$ dependent promiscuous reduction of very long pre-mRNA transcripts. Nucleic Acids Res 44(5):2093-2109

151. Shen W, De Hoyos CL, Sun H, Vickers TA, Liang XH, Crooke ST (2018) Acute hepatotoxicity of 2' fluoro-modified 5-10-5 gapmer phosphorothioate oligonucleotides in mice correlates with intracellular protein binding and the loss of DBHS proteins. Nucleic Acids Res 46(5):2204-2217

152. Senn JJ, Burel S, Henry SP (2005) Non-CpG-containing antisense 2'methoxyethyl oligonucleotides activate a proinflammatory response independent of Toll-like receptor 9 or myeloid differentiation factor 88. J Pharmacol Exp Ther 314(3):972-979

153. Shen W, Liang XH, Sun H, Crooke ST (2015) 2'-Fluoro-modified phosphorothioate oligonucleotide can cause rapid degradation of P54nrb and PSF. Nucleic Acids Res 43(9):4569-4578

154. Vickers TA, Crooke ST (2016) Development of a quantitative BRET affinity assay for nucleic acid-protein interactions. PLoS One 11(8):e0161930

155. Lima WF, Rose JB, Nichols JG, Wu H, Migawa MT, Wyrzykiewicz TK, Siwkowski AM, Crooke ST (2007) Human RNase H1 discriminates between subtle variations in the structure of the heteroduplex substrate. Mol Pharmacol 71(1):83-91 
156. Carroll JB, Warby SC, Southwell AL, Doty CN, Greenlee S, Skotte N, Hung G, Bennett CF, Freier SM, Hayden MR (2011) Potent and selective antisense oligonucleotides targeting single-nucleotide polymorphisms in the Huntington disease gene/allele-specific silencing of mutant huntingtin. Mol Ther 19(12):2178-2185

157. Freier S, Watt AT. in Antisense Drug Technology: Principles, Strategies, and Applications (ed. Crooke, S. T.)118-138 (CRC Press, 2007).

158. Wahlestedt C (2013) Targeting long non-coding RNA to therapeutically upregulate gene expression. Nat Rev Drug Discov 12(6):433-446.

\section{Publisher's Note}

Springer Nature remains neutral with regard to jurisdictional claims in published maps and institutional affiliations.

\section{Submit your manuscript to a SpringerOpen ${ }^{\circ}$ journal and benefit from:}

- Convenient online submission

- Rigorous peer review

- Open access: articles freely available online

High visibility within the field

- Retaining the copyright to your article

Submit your next manuscript at $\boldsymbol{\nabla}$ springeropen.com 